\title{
Effectiveness of Chilli Powder Incorporation to Microbial Loads, Physicochemical and Sensory Characteristics of Vietnamese Fermented Pork Roll (Nem Chua)
}

\author{
Nguyen Phuoc Minh \\ Faculty of Food Science and Technology, Thu Dau Mot University, Binh Duong Province, Vietnam.
}

\begin{abstract}
Vietnamese fermented pork roll (Nem Chua) is delicious by its distinctive and unforgettable sweet, crunchy and spicy feeling. It becomes a specialty of many regions in Vietnam. Recently consumers always pay much attention to hygiene. Spices and herbs can be considered as alternatives of artificial additives. This research evaluated the possibility of chilli powder incorporated to Vietnamese fermented pork roll

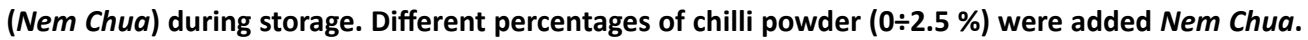
In 12 hour-interval, samples were taken to examine Enterobacteriaceae load, $\mathrm{pH}$, thiobarbituric acid value (TBA), total volatile bases nitrogen (TVB-N), overall acceptance (sensory score). During 60 hours of lactic fermentation, Enterobacteriaceae load decreased with the amount of chilli powder added. On the control sample, Enterobacteriaceae load increased during storage. Much more reduction of pH value was noticed when increasing chilli powder. There was a significant retardation of TBA and TVB-N accumulation by chilli powder addition. At $1.5 \%$ of chilli powder supplemented, the highest sensory score was noticed. Chilli powder would be a promising natural spice to control food hygiene and maintain physciochemical and sensory attributes of meat products.
\end{abstract}

Keywords: Chilli powder, Enterobacteriaceae, incorporation, Nem Chua, physciochemical, sensory

*Correspondence: nguyenphuocminh@tdmu.edu.vn

(Received: October 19, 2020; accepted: February 15, 2021)

Citation: Minh NP. Effectiveness of Chilli Powder Incorporation to Microbial Loads, Physicochemical and Sensory Characteristics of Vietnamese Fermented Pork Roll (Nem Chua). J Pure Appl Microbiol. 2021;15(1):390-395. doi:10.22207/JPAM.15.1.34

(c) The Author(s) 2021. Open Access. This article is distributed under the terms of the Creative Commons Attribution 4.0 International License which permits unrestricted use, sharing, distribution, and reproduction in any medium, provided you give appropriate credit to the original author(s) and the source, provide a link to the Creative Commons license, and indicate if changes were made. 


\section{INTRODUCTION}

Vietnamese fermented pork roll or Nem Chua is a meat roll with a sweet, sour, salty and spicy taste. The main ingredient in making Nem Chua is pork thigh. It is made from minced pork, sliced pigskin and a mixture of seasoning and garlic. These contents are mixed thoroughly before being wrapped with aromatic, fresh leaves (usually in banana leaves) into small, boxy rolls before being stored for natural fermentation process for three to five days in a cool place before eating. These stages help you store and keep their taste and ensure food hygiene. Consumers require safe and high-quality food. There is a great concern about food safety due to numerous food-borne disease outbreaks originated from pathogenic microbials. Food processors comonly utilize chemical preservatives and artificial antimicrobials to inhibit proliferation of spoilage and pathogenic microorganisms (Cichewicz and Thorpe, 1996). However, abuse of these substance is not good for human health. Therefore friendly-green antimicrobial like chilli pepper will be an alternative. The chilli pepper belongs to the Solanaceae family. The flavor and pungent power of chilli pepper are due to capsaicin. This chemical component has excellent biological properties influencing to the nervous, cardiovascular, and digestive systems (Brito-Argaez et al., 2009). Chilli pepper has been demonstrated as a rich source of antimicrobial and antifungal constituents (Seugill et al., 2014). Chilli contains numerous phytochemicals against cancer, diabetes, gastrointestinal diseases, pain, and metabolic syndrome (Bahare et al., 2018).

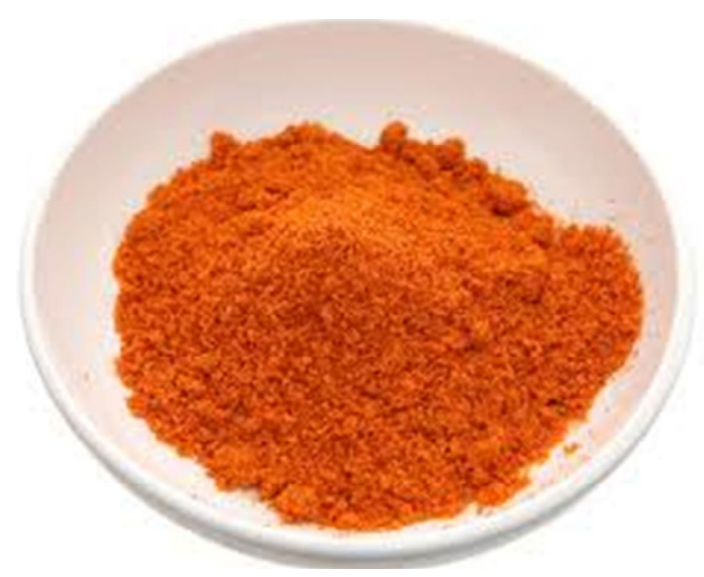

Fig. 1. Chilli powder
Objective of this research was to verify the impact of chilli powder percentage in supplementation to Nem Chua on Enterobacteriaceae load, physicochemical and sensory characteristics.

\section{MATERIAL AND METHOD Material}

Main ingredients in preparation of $\mathrm{Nem}$ Chua included $5 \mathrm{~kg}$ ground pork, $1 \mathrm{~kg}$ sliced pork skin, $100 \mathrm{~g}$ salt, $250 \mathrm{~g}$ minced garlic, $50 \mathrm{~g}$ pepper, $0.1 \%$ Lactobacillus acidophilus (109 cfu/g), chili powder (in different concentration, $0.5 \div 2.5 \%$ ). Chilli powder was commercially available from CJ Food Co. Ltd. Fresh pork and fat-free butt meat were collected from in reliable stores, ensuring clean and food safety. Meat must be not too dry, just a little chewy appropriate for processing $\mathrm{Nem}$ Chua. Ingredients were purchased from local market. Lactobacillus acidophilus in dry form was purchased from drug store. 3M-Petrilm plate was supplied from Van Dai Phat Co. Ltd, Vietnam. Chemical reagents were all analytical grade.

\section{Researching method}

Pork meat was kneaded thoroughly for 12 minutes until the meat became smooth and stick together. Minced meat was then mixed well with the prepared ingredients like garlic, pepper, chili powder $(0.5 \div 2.5 \%)$ and Lactobacillus acidophilus. A piece $(25 \mathrm{~g})$ of minced meat was put on a plastic film and begin rolling. At both ends of roll, plastic film was tighten to remove all air inside. These rolls were fermented at ambient temperature for 5 days ready for consumption. The fermented product (Nem chua) was taken to evaluate Enterobacteriaceae load, $\mathrm{pH}$, thiobarbituric acid value (TBA), total volatile bases nitrogen (TVB-N), overall acceptance (sensory score).

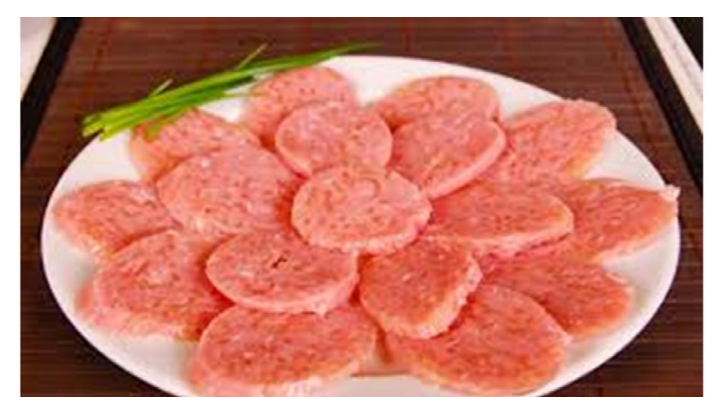

Fig. 2. Vietnamese fermented pork roll (Nem Chua) 


\section{Microbial, physicochemical and sensory evaluation}

Enterobacteriaceae load (cfu/g) was counted by $3 \mathrm{M}$-Petrilm plate. $\mathrm{pH}$ was determined by the method described by Ockerman (1985). Thiobarbituric acid value or TBA (mg malonaldehyde $/ \mathrm{kg}$ ) was determined following the procedure of Pearson et al. (1987). Total volatile nitrogen or TVB-N (mg/ $100 \mathrm{~g})$ was measured according to the method described by Winton and Winton (1958). Overall acceptance (sensory score) was evaluated by a group of panelist using 9-point Hedonic scale.

\section{Statistical analysis}

The experiments were run in triplicate with different groups of samples. The data were presented as mean \pm standard deviation. Statistical analysis was performed by the Statgraphics Centurion version XVI.

\section{RESULT AND DISCUSSION}

Enterobacteriaceae was an indicator of hygiene practice. Table 1 presented the impact of the added chilli powder $(0 \pm 2.5 \%)$ on Enterobacteriaceae (log cfu/g) in Nem Chua during storage. On the control sample, Enterobacteriaceae load increased during storage. Meanwhile, Enterobacteriaceae load decreased with the supplementation of chilli powder during storage. This implied that chilli powder had antimicrobial effect towards Enterobacteriaceae. One research verified the impact of various percentage of Capsicum chinense extracts on Staphylococcus aureus, Escherichia coli. Good antibacterial property was noticed at $75 \%$ Capsicum chinense extract counter Escherichia coli with $12 \mathrm{~mm}$ zone of inhibition. Meanwhile $75 \%$ Capsicum chinense extract presented maximum $11 \mathrm{~mm}$ zone counter Staphylococcus aureus (Jharna et al., 2018). Poultry farmers utilized $2.0 \%$ chilli powder supplemented into broiler feed as a beneficial alternative of the universal antibiotics (Hossain and Howlader, 2016). Chilli powder was demonstrated to have antimicrobial capability against Gram-negative and Gram-positive spoilage and pathogenic bacteria

Table 1. Effect of the added chilli powder (\%) on Enterobacteriaceae (log cfu/g) in Nem Chua during storage

\begin{tabular}{lcccccc}
\hline \multirow{2}{*}{$\begin{array}{c}\text { Storage } \\
\text { (hours) }\end{array}$} & \multicolumn{6}{c}{ Chilli powder (\%) } \\
\cline { 2 - 6 } & 0 & 0.5 & 1.0 & 1.5 & 2.0 & 2.5 \\
\hline 0 & $3.54 \pm 0.02^{\mathrm{a}}$ & $3.47 \pm 0.03^{\mathrm{a}}$ & $3.41 \pm 0.00^{\mathrm{a}}$ & $3.36 \pm 0.04^{\mathrm{a}}$ & $3.33 \pm 0.01^{\mathrm{a}}$ & $3.30 \pm 0.03^{\mathrm{a}}$ \\
12 & $4.79 \pm 0.01^{\mathrm{a}}$ & $3.04 \pm 0.00^{\mathrm{b}}$ & $2.84 \pm 0.01^{\mathrm{bc}}$ & $2.19 \pm 0.03^{\mathrm{c}}$ & $1.92 \pm 0.02^{\mathrm{cd}}$ & $1.15 \pm 0.01^{\mathrm{d}}$ \\
24 & $5.83 \pm 0.00^{\mathrm{a}}$ & $2.71 \pm 0.02^{\mathrm{b}}$ & $2.32 \pm 0.03^{\mathrm{bc}}$ & $1.86 \pm 0.02^{\mathrm{c}}$ & $1.37 \pm 0.00^{\mathrm{cd}}$ & $0.73 \pm 0.04^{\mathrm{d}}$ \\
36 & $6.47 \pm 0.03^{\mathrm{a}}$ & $2.16 \pm 0.04^{\mathrm{b}}$ & $1.97 \pm 0.02^{\mathrm{bc}}$ & $1.43 \pm 0.04^{\mathrm{c}}$ & $1.05 \pm 0.01^{\mathrm{cd}}$ & $0.46 \pm 0.02^{\mathrm{d}}$ \\
48 & $7.32 \pm 0.02^{\mathrm{a}}$ & $1.83 \pm 0.03^{\mathrm{b}}$ & $1.35 \pm 0.00^{\mathrm{bc}}$ & $1.02 \pm 0.02^{\mathrm{c}}$ & $0.74 \pm 0.00^{\mathrm{cd}}$ & $0.27 \pm 0.03^{\mathrm{d}}$ \\
60 & $8.01 \pm 0.01^{\mathrm{a}}$ & $1.29 \pm 0.02^{\mathrm{b}}$ & $1.04 \pm 0.03^{\mathrm{bc}}$ & $0.76 \pm 0.04^{\mathrm{c}}$ & $0.41 \pm 0.02^{\text {cd }}$ & $0.13 \pm 0.00^{\mathrm{d}}$ \\
\hline
\end{tabular}

Values are expressed as the mean of three repetitions; The values in a column followed by the same letter does not differ significantly ( $\alpha=5 \%)$.

Table 2. Effect of the added chilli powder (\%) on pH in Nem Chua during storage

\begin{tabular}{lcccccc}
\hline \multirow{2}{*}{$\begin{array}{c}\text { Storage } \\
\text { (hours) }\end{array}$} & \multicolumn{5}{c}{ Chilli powder (\%) } \\
\cline { 2 - 6 } & 0 & 0.5 & 1.0 & 1.5 & 2.0 & 2.5 \\
\hline 0 & $6.71 \pm 0.01^{\mathrm{a}}$ & $6.69 \pm 0.02^{\mathrm{a}}$ & $6.73 \pm 0.03^{\mathrm{a}}$ & $6.68 \pm 0.00^{\mathrm{a}}$ & $6.72 \pm 0.03^{\mathrm{a}}$ & $6.70 \pm 0.02^{\mathrm{a}}$ \\
12 & $6.55 \pm 0.00^{\mathrm{a}}$ & $6.48 \pm 0.03^{\mathrm{b}}$ & $6.41 \pm 0.02^{\mathrm{bc}}$ & $6.37 \pm 0.01^{\mathrm{c}}$ & $6.31 \pm 0.00^{\text {cd }}$ & $6.26 \pm 0.04^{\mathrm{d}}$ \\
24 & $6.27 \pm 0.03^{\mathrm{a}}$ & $6.13 \pm 0.01^{\mathrm{b}}$ & $6.07 \pm 0.00^{\mathrm{bc}}$ & $6.03 \pm 0.03^{\mathrm{c}}$ & $5.98 \pm 0.02^{\text {cd }}$ & $5.94 \pm 0.01^{\mathrm{d}}$ \\
36 & $6.01 \pm 0.01^{\mathrm{a}}$ & $5.94 \pm 0.02^{\mathrm{b}}$ & $5.89 \pm 0.03^{\mathrm{bc}}$ & $5.82 \pm 0.01^{\mathrm{c}}$ & $5.79 \pm 0.04^{\text {cd }}$ & $5.71 \pm 0.00^{\mathrm{d}}$ \\
48 & $5.92 \pm 0.00^{\mathrm{a}}$ & $5.81 \pm 0.04^{\mathrm{b}}$ & $5.77 \pm 0.01^{\mathrm{bc}}$ & $5.71 \pm 0.04^{\mathrm{c}}$ & $5.66 \pm 0.01^{\text {cd }}$ & $5.60 \pm 0.02^{\mathrm{d}}$ \\
60 & $5.81 \pm 0.02^{\mathrm{a}}$ & $5.73 \pm 0.00^{\mathrm{b}}$ & $5.68 \pm 0.02^{\mathrm{bc}}$ & $5.60 \pm 0.01^{\mathrm{c}}$ & $5.51 \pm 0.03^{\text {cd }}$ & $5.47 \pm 0.01^{\mathrm{d}}$ \\
\hline
\end{tabular}

Values are expressed as the mean of three repetitions; The values in a column followed by the same letter does not differ significantly $(\alpha=5 \%)$. 
Minh | J Pure Appl Microbiol | 15(1):390-395 | March 2021 | https://doi.org/10.22207/JPAM.15.1.34

Table 3. Effect of the added chilli powder (\%) on TBA (mg malonaldehyde/kg) in Nem Chua during storage

\begin{tabular}{lcccccc}
\hline \multirow{2}{*}{$\begin{array}{c}\text { Storage } \\
\text { (hours) }\end{array}$} & \multicolumn{7}{c}{ Chilli powder (\%) } \\
\cline { 2 - 6 } & 0 & 0.5 & 1.0 & 1.5 & 2.0 & 2.5 \\
\hline 0 & $0.11 \pm 0.03^{\mathrm{a}}$ & $0.09 \pm 0.01^{\mathrm{a}}$ & $0.10 \pm 0.02^{\mathrm{a}}$ & $0.13 \pm 0.04^{\mathrm{a}}$ & $0.08 \pm 0.02^{\mathrm{a}}$ & $0.12 \pm 0.03^{\mathrm{a}}$ \\
12 & $0.39 \pm 0.02^{\mathrm{a}}$ & $0.17 \pm 0.04^{\mathrm{b}}$ & $0.15 \pm 0.01^{\mathrm{bc}}$ & $0.14 \pm 0.00^{\mathrm{bc}}$ & $0.13 \pm 0.01^{\mathrm{c}}$ & $0.12 \pm 0.00^{\mathrm{c}}$ \\
24 & $0.67 \pm 0.01^{\mathrm{a}}$ & $0.22 \pm 0.00^{\mathrm{b}}$ & $0.19 \pm 0.03^{\mathrm{bc}}$ & $0.17 \pm 0.01^{\mathrm{bc}}$ & $0.15 \pm 0.03^{\mathrm{c}}$ & $0.13 \pm 0.02^{\mathrm{c}}$ \\
36 & $0.95 \pm 0.04^{\mathrm{a}}$ & $0.27 \pm 0.03^{\mathrm{b}}$ & $0.25 \pm 0.04^{\mathrm{bc}}$ & $0.22 \pm 0.02^{\mathrm{bc}}$ & $0.19 \pm 0.01^{\mathrm{c}}$ & $0.17 \pm 0.03^{\mathrm{c}}$ \\
48 & $1.24 \pm 0.02^{\mathrm{a}}$ & $0.34 \pm 0.01^{\mathrm{b}}$ & $0.29 \pm 0.02^{\mathrm{bc}}$ & $0.26 \pm 0.00^{\mathrm{bc}}$ & $0.23 \pm 0.02^{\mathrm{c}}$ & $0.21 \pm 0.01^{\mathrm{c}}$ \\
60 & $1.68 \pm 0.00^{\mathrm{a}}$ & $0.39 \pm 0.02^{\mathrm{b}}$ & $0.34 \pm 0.00^{\mathrm{bc}}$ & $0.29 \pm 0.03^{\mathrm{bc}}$ & $0.25 \pm 0.00^{\mathrm{c}}$ & $0.23 \pm 0.02^{\mathrm{c}}$ \\
\hline
\end{tabular}

Values are expressed as the mean of three repetitions; The values in a column followed by the same letter does not differ significantly $(\alpha=5 \%)$.

Table 4. Effect of the added chilli powder (\%) on TVB-N (mg/ $100 \mathrm{~g})$ in Nem Chua during storage

\begin{tabular}{lcccccc}
\hline \multirow{2}{*}{$\begin{array}{c}\text { Storage } \\
\text { (hours) }\end{array}$} & \multicolumn{7}{c}{ Chilli powder (\%) } \\
\cline { 2 - 6 } & 0 & 0.5 & 1.0 & 1.5 & 2.0 & 2.5 \\
\hline 0 & $1.18 \pm 0.00^{\mathrm{a}}$ & $1.21 \pm 0.04^{\mathrm{a}}$ & $1.19 \pm 0.01^{\mathrm{a}}$ & $1.22 \pm 0.02 \mathrm{a}$ & $1.23 \pm 0.00^{\mathrm{a}}$ & $1.20 \pm 0.02^{\mathrm{a}}$ \\
12 & $2.43 \pm 0.04^{\mathrm{a}}$ & $1.65 \pm 0.01^{\mathrm{b}}$ & $1.47 \pm 0.03^{\mathrm{bc}}$ & $1.38 \pm 0.01^{\mathrm{c}}$ & $1.31 \pm 0.02^{\mathrm{cd}}$ & $1.24 \pm 0.01^{\mathrm{d}}$ \\
24 & $3.97 \pm 0.02^{\mathrm{a}}$ & $2.07 \pm 0.03^{\mathrm{b}}$ & $1.92 \pm 0.00^{\mathrm{bc}}$ & $1.71 \pm 0.03^{\mathrm{c}}$ & $1.58 \pm 0.01^{\mathrm{cd}}$ & $1.43 \pm 0.03^{\mathrm{d}}$ \\
36 & $5.83 \pm 0.03^{\mathrm{a}}$ & $2.28 \pm 0.00^{\mathrm{b}}$ & $2.11 \pm 0.01^{\mathrm{bc}}$ & $1.98 \pm 0.00^{\mathrm{c}}$ & $1.73 \pm 0.04^{\mathrm{cd}}$ & $1.61 \pm 0.02 \mathrm{~d}$ \\
48 & $7.64 \pm 0.01^{\mathrm{a}}$ & $2.49 \pm 0.02^{\mathrm{b}}$ & $2.32 \pm 0.00^{\mathrm{bc}}$ & $2.14 \pm 0.03^{\mathrm{c}}$ & $1.97 \pm 0.01^{\mathrm{cd}}$ & $1.82 \pm 0.00^{\mathrm{d}}$ \\
60 & $9.16 \pm 0.02^{\mathrm{a}}$ & $2.71 \pm 0.00^{\mathrm{b}}$ & $2.55 \pm 0.03^{\mathrm{bc}}$ & $2.38 \pm 0.01^{\mathrm{c}}$ & $2.16 \pm 0.03^{\mathrm{cd}}$ & $2.03 \pm 0.01^{\mathrm{d}}$ \\
\hline
\end{tabular}

Values are expressed as the mean of three repetitions; The values in a column followed by the same letter does not differ significantly $(\alpha=5 \%)$.

(Gottardi et al., 2016). The antimicrobial capacity of chilli powder was strongly related to capsaicin and dihydrocapsaicin (Dorantes et al., 2000). Supplementation of mustard powder could reduce E.coli load to uncountable levels (Hosseinvand and Sorkhinejad, 2019).

Table 2 showed the influence of chilli powder to $\mathrm{pH}$ in Nem Chua during storage. Much more reduction of $\mathrm{pH}$ value was noticed when increasing chilli powder. This could be explained that chilli powder had possitive impact to Lactobacillus acidophilus in supporting the lactic acid fermentation. Supplementation of chilli powder was reported to enhance the amount of I-lactate produced by L. acidophilus (Smriti et al., 2013).

Malondialdehyde originated from the oxidation of polyunsaturated fatty acids is an indicator of lipid peroxidation (Hodges et al., 1999). Table 3 revealed the significant effect of chilli powder in retardation of TBA accumulation in Nem Chua during storage. It could be explained by the antimicrobial mechanism towards pathogen and spoilage microorganism. Antioxidant property of chilli powder was associated to its phenolic, flavonoid, vitamin and carotenoid (Morales-Soto et al., 2013). Capsaicin in chilli powder could retard cooper ion-induced lipid peroxidation decreasing the formation of thiobarbituric acid (Naidu and Thippeswamy, 2002). Apart from capsaicin and dihydrocapsaicin; sinapoyl and feruloyl glycosides also responsible for antioxidant ability of chilli pepper (Materska and Perucka, 2005).

TVB-N value also decreased by the incorporation of chilli powder to Nem Chua in storage Table 4). TVB-N was an index of amino acid decomposition by bacteria. It directly released spoilage odors and flavors (Gill, 1983; Kanemaru et al., 1990; Mayerhauser, 2001). In a similar research, the grilled meat slices supplemented mustard powder had lower $\mathrm{pH}, \mathrm{TBA}$ and TVB-N values by accelerating amount of mustard powder (Hosseinvand and Sorkhinejad, 2019).

With the addition of chilli powder, overall 
Table 5. Effect of the added chilli powder (\%) on sensory score in Nem Chua during storage

\begin{tabular}{lcccccc}
\hline \multirow{2}{*}{$\begin{array}{c}\text { Storage } \\
\text { (hours) }\end{array}$} & \multicolumn{7}{c}{ Chilli powder (\%) } \\
\cline { 2 - 6 } & 0 & 0.5 & 1.0 & 1.5 & 2.0 & 2.5 \\
\hline 0 & $4.15 \pm 0.04^{\mathrm{a}}$ & $4.17 \pm 0.02^{\mathrm{a}}$ & $4.16 \pm 0.03^{\mathrm{a}}$ & $4.14 \pm 0.00^{\mathrm{a}}$ & $4.18 \pm 0.03^{\mathrm{a}}$ & $4.13 \pm 0.00^{\mathrm{a}}$ \\
12 & $5.03 \pm 0.01^{\mathrm{d}}$ & $5.39 \pm 0.00^{\mathrm{c}}$ & $5.97 \pm 0.02^{\mathrm{bc}}$ & $7.25 \pm 0.03^{\mathrm{a}}$ & $6.93 \pm 0.01^{\mathrm{ab}}$ & $6.45 \pm 0.03^{\mathrm{b}}$ \\
24 & $5.24 \pm 0.03^{\mathrm{d}}$ & $6.14 \pm 0.01^{\mathrm{c}}$ & $6.58 \pm 0.03^{\mathrm{bc}}$ & $7.79 \pm 0.01^{\mathrm{a}}$ & $7.38 \pm 0.02^{\mathrm{ab}}$ & $6.97 \pm 0.01^{\mathrm{b}}$ \\
36 & $5.72 \pm 0.00^{\mathrm{d}}$ & $6.92 \pm 0.03^{\mathrm{c}}$ & $7.36 \pm 0.00^{\mathrm{bc}}$ & $8.61 \pm 0.03^{\mathrm{a}}$ & $8.24 \pm 0.00^{\mathrm{ab}}$ & $7.89 \pm 0.02^{\mathrm{b}}$ \\
48 & $6.35 \pm 0.02^{\mathrm{d}}$ & $7.37 \pm 0.00^{\mathrm{c}}$ & $7.74 \pm 0.02^{\mathrm{bc}}$ & $8.75 \pm 0.02^{\mathrm{a}}$ & $8.47 \pm 0.03^{\mathrm{ab}}$ & $8.01 \pm 0.04^{\mathrm{b}}$ \\
60 & $7.14 \pm 0.01^{\mathrm{d}}$ & $7.89 \pm 0.02^{\mathrm{c}}$ & $8.23 \pm 0.01^{\mathrm{bc}}$ & $8.94 \pm 0.00^{\mathrm{a}}$ & $8.80 \pm 0.02^{\mathrm{ab}}$ & $8.59 \pm 0.00 \mathrm{~b}$ \\
\hline
\end{tabular}

Values are expressed as the mean of three repetitions; The values in a column followed by the same letter does not differ significantly $(\alpha=5 \%)$.

acceptance of Nem Chua would be better (Table 5). At $1.5 \%$ of chilli powder supplemented, the highest sensory score was noticed. Capsaicin in chilli had organoleptic effects by its strong pungency (Westerterp-Plantenga et al., 2005; Diepvens et al., 2007). Hence, too much supplementation of chilli powder percentage was limited because it will greatly impact on taste of the product. Incorporation of $2 \%$ mustard powder strongly enhanced organoleptic property of the grilled meat slices (Hosseinvand and Sorkhinejad, 2019).

\section{CONCLUSION}

Capsaicin is the most common bioactive component of chilli pepper. This spice has many applications in food industry. This research verified the influence of chilli powder supplemented to Vietnamese fermented pork roll (Nem Chua). Various microbial, physicochemical and sensory characteristics of Nem Chua had been thoroughly examined. Results showed that chilli powder had antimicrobial effect against Enterobacteriaceae. Chilli powder also had antioxidant capacity to retard lipid and amino acid decomposition. Better improvement of overall acceptance was recorded by chilli powder incorporation into the Vietnamese fermented pork roll.

\section{ACKNOWLEDGMENTS}

We would like to express our heartfelt thanks to Dr. Nguyen Hong Tuoi for providing assistance on methods. Thanks to Rainbow Co., Ltd. for providing assistance on bioinformatics analysis. The authors were grateful to Dr. Lam Thanh Buu for English editing of the manuscript.
We would like to thank Mrs Le Thi Kieu Oanh for the collaboration during the research.

\section{FUNDING}

This study was supported by Thu Dau Mot University, Binh Duong province, Vietnam.

\section{DATA AVAILABILITY}

All datasets generated or analyzed during this study were included in the manuscript.

\section{ETHICS STATEMENT}

This article did not contain any studies with human participants or animals performed by any of the authors.

\section{REFERENCES}

1. Brito-Argaez L, Moguel-Salazar F, Zamudio F, GonzalezEstrada T, Islas-Flores I. Characterization of a capsicum chinense seed peptide fraction with broad antibacterial activity. Asian Journal of Biochemistry. 2009;4(3):7787. doi: 10.3923/ajb.2009.77.87

2. Cichewicz $\mathrm{RH}$, Thorpe PA. The antimicrobial properties of chile peppers (Capsicum species) and their uses in Mayan medicine. J Ethnopharmacol. 1996;52(2):61-70. doi: 10.1016/0378-8741(96)01384-0

3. Diepvens K, Westerterp KR, Westerterp-Plantenga MS. Obesity and thermogenesis related to the consumption of caffeine, ephedrine, capsaicin, and green tea. Am J Physiol Regul, Integr Comp Physiol. 2007;292(1):77-85. doi: 10.1152/ajpregu.00832.2005

4. Dorantes L, Colmenero R, Hernandez $H$, Mota L, Jaramillo ME, Fernandez E, Solano C. Inhibition of growth of some foodborne pathogenic bacteria by Capsicum annum extracts. Int J Food Microbiol. 2000;57(1-2):125-128. doi: 10.1016/S01681605(00)00216-6

5. Gill CO. Meat spoilage and evaluation of potential storage life of fresh meat. J Food Prot.1983;46(5):444452. doi: 10.4315/0362-028X-46.5.444

6. Gottardi D, Bukvicki D, Prasad S, Tyagi AK Beneficial 
effects of spices in food preservation and safety. Front Microbiol. 2016;7:1394. doi: 10.3389/ fmicb.2016.01394

7. Hodges DM, DeLong JM, Forney CF, Prange RK. Improving the thiobarbituric acid-reactive-substances assay for estimating lipid peroxidation in plant tissues containing anthocyanin and other interfering compounds. Planta. 1999;207:604-611. doi: 10.1007/ s004250050524

8. Hossain MM, Howlader AJ. Evaluation of suitable doses of hot chilli powder as effective alternative of antibiotics on growth performance of broiler. International Journal of Animal Resources. 2016;1(2):45-54.

9. Hosseinvand A, Sorkhinejad A. Evaluation of mustard powder as natural ingredient to reduce antimicrobial levels and physichochemical properties in beef. Madridge J Food Technol. 2019;4:170-175. doi: $10.18689 / \mathrm{mjft}-1000126$

10. Jharna D, Manab D, Krishna G. Antimicrobial activity of chilli extracts (Capsicum chinense) against food borne pathogens Escherichia coli and Staphylococcus aureus. International Journal of Research and Analytical Reviews. 2018;5(4):717-720.

11. Kanemaru K, Miyamoto T. Inhibitory effects on the growth of several bacteria by brown mustard and Allyl isothiocyanate. Nippon Shokuhin Kogyo Gakkaishi. 1990;37(10):823-829. doi: 10.3136/ nskkk1962.37.10_823

12. Materska M, Perucka I. Antioxidant activity of the main phenolic compounds isolated from hot pepper fruit (Capsicum annuum L.). J Agric Food Chem. 2005;53(5):1750-1756. doi: 10.1021/jf035331k

13. Mayerhauser CM. Survival of enterohemorrhagic Escherichia coli 0157:H7 in retail mustard. J Food Prot. 2001;64(6):783-787. doi: 10.4315/0362-028X64.6.783

14. Morales-Soto A, Gomez-Caravaca AM, Garcia-Salas $P$, Segura-Carretero A, Fernandez-Gutierrez A.
High-performance liquid chromatography coupled to diode array and electrospray time-of-flight mass spectrometry detectors for a comprehensive characterization of phenolic and other polar compounds in three pepper (Capsicum annuum L.) samples. Food Res Int. 2013;51(2):977-984. doi: 10.1016/j.foodres.2013.02.022

15. Naidu KA, Thippeswamy NB. Inhibition of human low density lipoprotein oxidation by active principles from spices. Mol Cell Biochem. 2002;229(1-2):19-23. doi: 10.1023/A:1017930708099

16. Ockerman HW. Quality control of post-mortem muscle tissue. Department of Animal Sciences. The Ohio State University; Columbus, OH, USA. 1985.

17. Pearson D, Egan H, Kirk RS, Sawyer R. Pearson's chemical analysis of foods. Longman Scientific and Technical. 1987.

18. Salehi B, Hernandez-Alvarez AJ, Contreras MM, et al. Potential phytopharmacy and food applications of Capsicum spp.: A comprehensive review. Nat Prod Commun. 2018;13(11):1543-1556. doi: 10.1177/1934578X1801301133

19. Seugill K, Minkyu P, Seon-In Y et al. Genome sequence of the hot pepper provides insights into the evolution of pungency in Capsicum species. Nature. 2014;46:270-278.

20. Smriti S, Sriyans J, Girija NN, Srinivasan R. Capsicum annuum enhances L-lactate production by Lactobacillus acidophilus: Implication in curd formation. J Dairy Sci. 2013;96(7):4142-4148. doi: 10.3168/jds.2012-6243

21. Westerterp-Plantenga MS, Smeets A, Lejeune MP. Sensory and gastrointestinal satiety effects of capsaicin on food intake. Int J Obes. 2005;29(6):682-688. doi: 10.1038/sj.ijo.0802862

22. Winton AL, Winton KB. Oxide distillation volumetric method for the determination of volatile nitrogen. In: Wikysons J (ed). The Analysis of Food. New York, Chapman and Hull, London. 1958:840. 